\title{
Abundance of palm frond borer Phonapate frontalis (Fah.) (Coleoptera: Bostrichidae) with reference to potential use of garlic extract for its control in Siwa Oasis, Egypt
}

\author{
Ahmed I. Imamid
}

\begin{abstract}
Palm frond borer Phonapate frontalis F. (Coleoptera: Bostrichidae) has been recently detected as an economic pest of date palm orchards at Siwa Oasis, Egypt. The infestation symptoms appeared in the form of frond break and viscous oozes at the fracture points. The present study aimed to monitor the population fluctuation of $P$. frontalis adults, using light traps during 2016 season and to test the capability of the methanolic garlic extract to deter the beetles and consequently reduce frond breakage. The average monthly monitoring revealed minor Phonapate adult catches during January and November with maximum numbers during June-August. Coinciding with the surveillance of Phonapate adults, broken fronds were periodically monitored. The highest average breakage was noticed at the period extended from May to September. Accordingly, fortnight spraying program had been designed and commenced to cover such period. At the end of the proposed program, the corrected infestation percentages recorded about 43.11, 44.89, and 42.22\% at 1000, 2000, and 3000 ppm of the methanolic garlic extract concentrations, respectively. Accordingly, garlic extract succeeded to diminish palm frond infestation through its capability to deter adult beetles. Engagement of cost competitive treatment as a P. frontalis niche (palm fronds) management tool in the proposed IPM program could support the sustainable pest management in the date palm orchards.
\end{abstract}

Keywords: Palm frond borer, Phonapate frontalis, Abundance, Niche management, Garlic extract, Egypt

\section{Introduction}

Date palm, Phoenix dactylifera L., is one of the most cultivated trees in the desert areas of many countries (Abass et al. 2016). As the global annual date production is estimated by about 7.4 million tons, Arab countries are considered as the lead producers by about $70 \%$ (FAOSTAT 2011). Out of which, Egypt comes on the head of the date producer list by about 11 million fruitful date palm trees with estimated production of about $1,115,000$ tons annually (Erskine et al. 2003). Egyptian Oases at the western desert are one of the main date palm cultivation areas. In which semi-dry varieties are the dominant ones due to their adaptation to the prevailing environmental conditions ( $\operatorname{Riad} 1993)$.

Correspondence: aiimmam@yahoo.com

Desert Research Center, 1 Mathaf El-Matariya St., B.O.P: 11753 Matariya, Cairo, Egypt
Insect pest invasion is one of the major detrimental factors that could threaten date palm production on both Egyptian and global levels. Out of date palm pest complex, palm borers are ranked as the most dangerous date palm attackers. Where the tunnels excavated within the internal palm tissues (trunk or frond or spathe) by larvae and/or adults that weaken the tree through hindering the passage of nutrients and water facilitate the opportunity of fungal or bacterial infestation and may cause the breakage of the infested parts. The chronic mode of infestation progress of most borer species beside the difficulty for early infestation detection, the rareness of detailed studies regarding this group of pests, and the unawareness of date palm farmers with the good agriculture practices to manage them may be another reasonable key for more exacerbated situation (Al-Deeb et al. 2012; and Khalaf et al. 2017).

\section{Springer Open}

(c) The Author(s). 2019 Open Access This article is distributed under the terms of the Creative Commons Attribution 4.0 International License (http://creativecommons.org/licenses/by/4.0/), which permits unrestricted use, distribution, and reproduction in any medium, provided you give appropriate credit to the original author(s) and the source, provide a link to the Creative Commons license, and indicate if changes were made. 
Siwa is one of the Egyptian well-known oases globally. At Siwa Oasis, date palm trees are invaded by a group of economic insect pests that target different parts synchronizing different growing stages of the trees (Imam 2012). Among these herbivorous species, adults of the palm frond borer, Phonapate frontalis (F.) (Coleoptera: Bostrichidae), were recently recorded by the light trap and by their infestation symptoms (breaking of the palm green fronds) in May 2015 (Fig. 1). According to Al-Haideri and Al-Hafidh (1986), P. frontalis was not considered among the major economic pests of palm trees at the near east and North Africa. In contrary, at Al-Wahat regions, Libya, Al-Ogale (2003) recorded infestation rates of 10.2, 11.1, 9.6, and 10.3\% during May, June, July and August months, respectively. P. frontalis adult is a nocturnal insect; its flight period is extended either from May to October (Khattab and Helal 1978) or from March to October (Al-Ogale (2003)) according to the monitored subspecies and the prevailing weather conditions. The highest catch of Phonapate adults was recorded between June and September. Adults of $P$. frontalis have the capability to mine tunnels within the green frond tissues and within which the couples are met for mating. A viscous liquid is oozed as a result of the tunnel excavation process. The beginning of frond breakage symptom was noticed in March with a remarkable increase in the breaking percentages at the period May-August, coinciding with the flight period of adults (Bitaw and Ben-Saad 1990).

Garlic, Allium sativum L., extract is one of the promising alternatives against arthropod pests (Karunamoorthi and Hailu 2014). Different forms of garlic extracts showed noticeable efficacy as eco-friendly protectants against different species and stages of pests such as stored grain pests (Nwachukwu and Asawalam 2014).

The objective of the present study was to estimate the population fluctuation of the palm frond borer and to test the efficacy of methanolic garlic extract in either repel or deter Phonapate beetles and consequently reduce frond breakage.

\section{Materials and methods}

Study site

Siwa (Matrouh Governorate) is a natural depression situated at the northern corner of the Egyptian western desert, about $300 \mathrm{~km}$ from the Mediterranean coast. The oasis is one of the main date palm assemblage points in Egypt, especially the semi-dry "saidi" variety. Out of all Siwa's villages, Al-Herak (29 $11^{\prime} 56.36^{\prime \prime} \mathrm{N}$ and $25^{\circ} 29$ $58.56^{\prime \prime}$ E) date palm orchards showed aggressive attack of the palm frond borer. Accordingly, all the proposed studies were implemented therein.

\section{Experimental design \\ Abundance of the palm frond borer}

During 2016 date growing season, two light traps (Ultra violet Robinson's vapor light trap) (Robinson and Robinson 1950) were installed in the middle of one date palm orchard that had about 100 palm trees of saidi variety. The palm trees under investigation are fruitful trees with about 12 years old and 1.5 to 2 $\mathrm{m}$ height. So, the trap was hanged on a $2 \mathrm{~m}$ holder to be in the level of date palm fronds. The farm receives all the traditional agriculture practices that implemented in the majority of Siwa date palm orchards. Monthly monitoring of the trap catches was carried

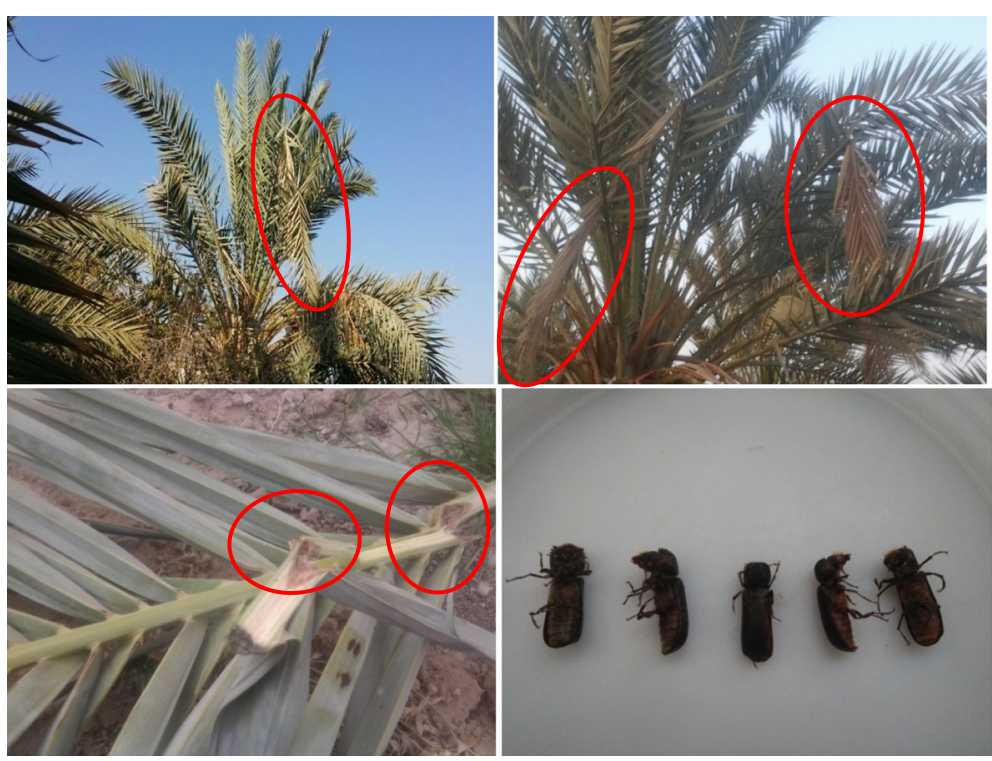

Fig. 1 Infestation symptoms and adult stage of the palm frond borer, Phonapate frontalis, at the date palm groves of Siwa Oasis (2015 season) 
out throughout the year from January to December counting the number of collected $P$. frontalis adults.

During 2016 season, the periodical breakage of palm fronds was also recorded. In order to conduct this trial, 15 date palm trees were kept under investigation; all infested (broken) fronds that remained hanging on the trees from the previous season were cut before the onset of January 2016. The commencement, fluctuation, the ending, and the period of palm frond fracture were crucially noticed and recorded.

\section{Preparation of methanolic garlic extract}

Extraction process had been carried out according to Hafiz et al. (2012) with certain modifications. Fixed amount of dry and cleaned garlic bulbs (about 250 g) was well crushed using an electric grinder. The grinded garlic cake was transferred to a clean glass beaker and soaked in an adequate volume of pure methanol (about $750 \mathrm{ml}$ ) for 2 days to facilitate the extraction of the active compounds (ingredients) in the supernatant (liquid extract). The methanolic garlic solution was filtrated out, using a filter paper (Whatman no. 1), and the supernatant is subjected to a mild air current for evaporating the methanol. The obtained solid ingredient was weighted to estimate the extracted amount and then used to prepare three aqueous concentrations (3000, 2000 , and $1000 \mathrm{ppm}$ ) to assess their potentiality to decrease the infestation percentages of $P$. frontalis in a comparative pilot experiment.

\section{Bioassay test of garlic extracts}

During 2017 date palm growing season, four palm tree demonstration plots, that had previous infestation history with frond borer, were selected at Al-Herak village. Each plot had about 15 fruitful trees, aged about 12 years old, with about $50 \mathrm{~m}$ separating distance between the examined plots. The spraying schedule of the prepared aqueous garlic extract started from early April to the end of August biweekly. Spraying procedure was carried out through adjusting the outlet nozzle of the sprayer to produce a thin film of the solution to fulfill complete coverage of the whole targeted fronds (each tree received about $8 \mathrm{l}$ ). The recommended dose of Triton was added to the $20 \mathrm{l}$ knapsack sprayer as a surfactant agent. The previously selected plots had been subjected to this scheduled program, while the fourth one received only the Triton solution to serve as a blank treatment. The broken fronds were counted and removed monthly (following the two sprays). By the end of the scheduled spraying program, infestation percentages were calculated and corrected (Henderson and Tilton 1955).

\section{Statistical analysis}

For statistical analysis of obtained data, one-way analysis of variance (ANOVA) was applied. Means were compared using Duncan's multiple range test by SPSS. Comparison was carried out with the least significant difference (LSD) test at $P \leq 0.05$ (IBM SPSS Statistics for Windows 2013).

\section{Results and discussion \\ Surveillance of $P$. frontalis adults}

Population fluctuation of $P$. frontalis adults was monitored under Siwa Oasis palm orchard conditions in 2016 date growing season (Fig. 2). The average monthly monitoring revealed minor Phonapate adult catches in January and November and with zero catches in December. The progress of the growing season showed fluctuated patterns of the flight activity of $P$. frontalis adults. Average catch period of Phonapate beetles recorded the

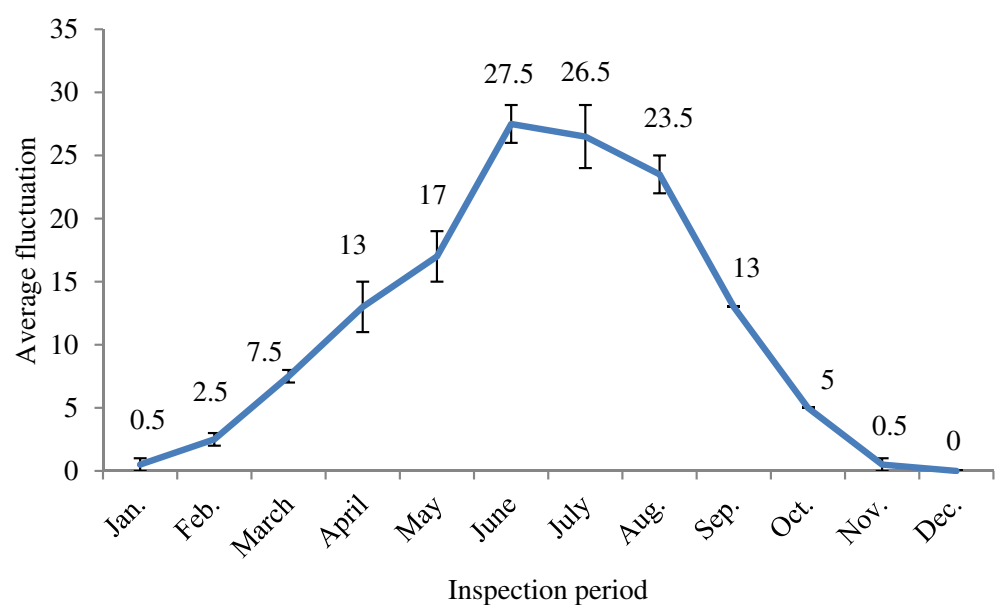

Fig. 2 Average monthly fluctuation of Phonapate frontalis adults (mean catch/2 traps \pm SE) at Siwa date palm groves (2016 season) 


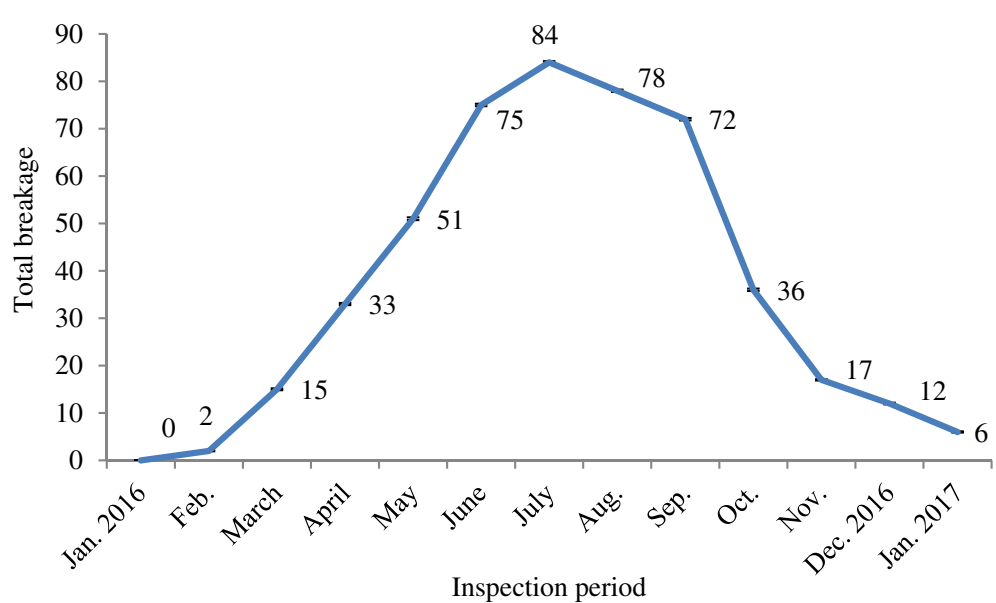

Fig. 3 Total monthly frond breakage/15 trees at Siwa date palm groves (from January 2016 to January 2017)

maximum from June to August, while proportional decline was the case in the remaining months (Fig. 2). Coincided with the surveillance of $P$. frontalis adults, frond breakage was also periodically recorded as a total frond breakage/15 trees (Fig. 3), and the average breakage/tree was graphically represented in Fig. 4. In this regard, the obtained data revealed that the average fronds breakage showed the highest values at the period extended from May 2016 to September (3.4 and 4.8 fronds breakage, respectively), with a maximum average breakage in July (5.6 fronds). The total frond breakage during the whole inspection period recorded was 481 .

The present findings revealed that infestation symptoms of palm front borer were noticed near the tops of the previously formed fronds and never been recorded at the basal half of the fronds, i.e., the newly formed fronds showed zero infestation. P. frontalis infestation spot was also detected by Khalaf and Alrubiae (2016) on the middle portion of the frond. Another noteworthy point was the equivalent distribution pattern of the infested fronds on the perimeters of the investigated tree canopies. The variation in the susceptibility of date palm varieties to Phonapate infestation was stated by Khalaf and Al-Taweel (2014) with higher tendency of the green fronds of the semi-dry "saidi" variety to break more than the other ones. Similar note was also observed at Siwa's date palm groves. The chewing behavior of this bostrichid beetle induces powder-like material of the internal frond tissues that could extremely affect the photosynthesis process and also makes the fronds unsuitable for handcraft manufactures or wood industries (Liu et al. 2008 and Al-Deeb and Khalaf 2015). The deterioration of sapwood due to the excavation behavior of both larval and adult stages of $P$. frontalis beside the absence of vascular cambium or lateral meristem in the date palm tree (monocotyledonous species) may exacerbate the problem

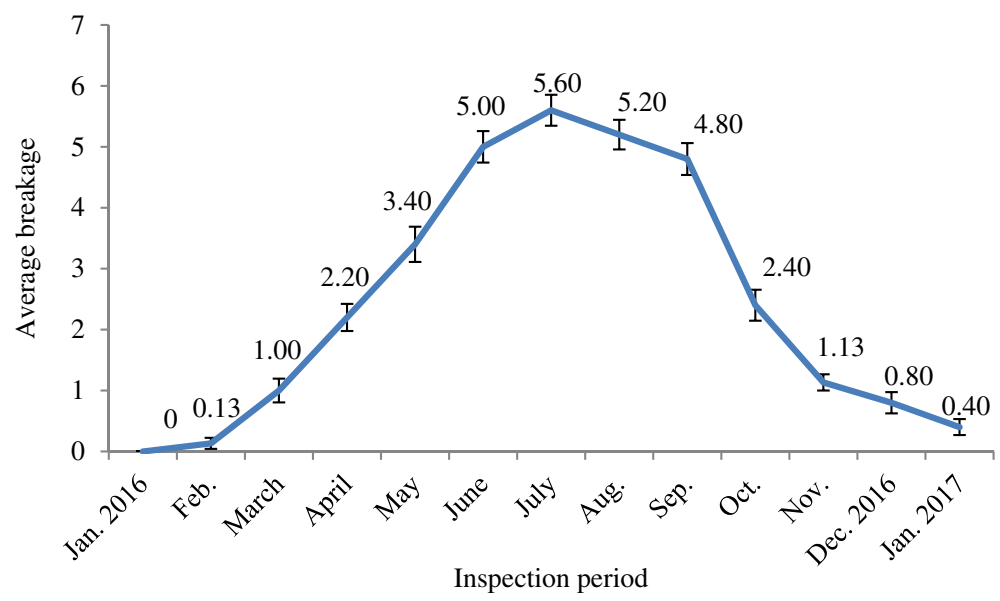

Fig. 4 Average monthly frond breakage/1 tree at Siwa date palm groves (from January 2016 to January 2017) 


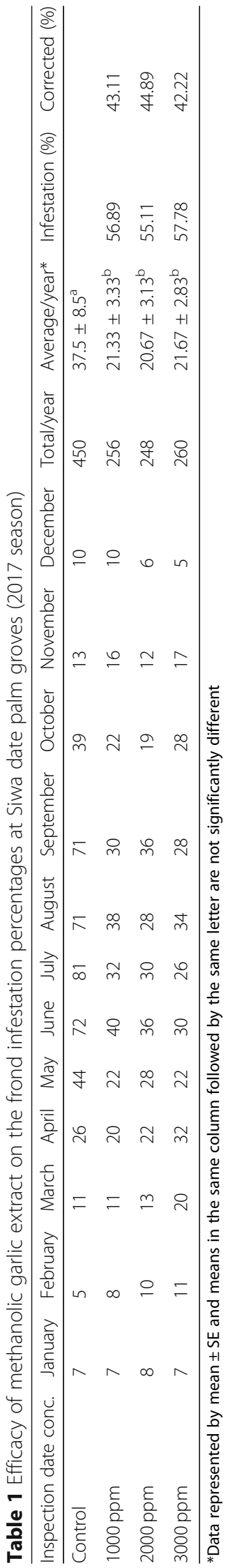


as there is no chance for the compensation or formation of newly vascular bundles instead of the destroyed ones (Broschat 2013). Flight activity of Phonapate borer showed relative compatible pattern with a lot of relevant published data. Where the nocturnal activity was stated by Al-Ogale (2003) and Ataia (2007). The earliest commencement of the flight period at Siwa's date palm groves comparing to the pre-mentioned studies could be returned to the relative warmness of Siwa Oasis due to its low topographic nature (Misak et al. 1997) and/or the intensive cultivation pattern of date palm orchards, especially in the old ones, that may modify the climate of date palm agro-ecosystem in favor of the early emergence of $P$. frontalis beetles. Flight activity period of Phonapate beetles showed more sense through its linkage with the excavated date palm fronds. In this regard, the obtained results revealed synchronized patterns between frond breakage and beetle activity in terms of the onset of frond fracture and beetle appearance, proportional progress, and peak period of both items in a time-dependent manner. The frond breakage at the period of zero beetle detection could be returned to effect of wind on the previously tunneled fronds (Al-Ogale 2003).

\section{Bioassay test of garlic extracts}

Table 1 shows the monthly break of palm fronds at each previously selected plots, both the untreated and the plots that received garlic extract concentrations. The tabulated data revealed the natural state of broken fronds at the first 3 months of the season. Where, the number of infested fronds in January, February, and March was the lowest comparing to the upcoming months, with a slight increase at the frond fracture patterns in March. Accordingly, the onset of fortnight spraying programs was synchronized with such frond breaking progress state. At the end of the first two sprays that implemented in April, infested frond showed further progress recording 20,22, and 32 broken fronds by using 1000,2000 , and $3000 \mathrm{ppm}$ garlic extract concentrations, respectively. Similar frond breakage trend was also recorded at the check plot (26 broken fronds). Thereafter, mild increase in the infested fronds was recorded in the treated plots, following the third and fourth sprays comparing to an obvious breakage of the control fronds. Both treated and check plots suffered the highest frond breakage at the period that extended from June to September. The average estimated breakage at this period (summation of the fractured fronds at the 4 months/4) was 73.75 at the control trial comparing to $35,32.5$, and 29.5 at the sprayed plots, respectively. This infestation reduction confirmed the potentiality of garlic extracts as a promising bio-candidate. The month of October coincided with low representation of Phonapate adults and frond breakage as well. The estimation of total infested fronds, at the end of the season, revealed 450 infested fronds at the check treatment comparing to an obvious infestation decline, following the proposed spraying program. The corrected infestation percentages recorded about 43.11, 44.89, and $42.22 \%$ at the sprayed garlic concentrations, respectively. Table 1 illustrates that treatment with methanolic garlic extract has significantly reduced the infestation with frond borer $(F=2.62 ; P=0.04)$.

According to this field study, the proposed program had been designed and implemented to cover the high risk period (the period of overestimated Phonapate beetles and consequently high broken fronds) to make the date palm fronds un- or less favorable as a harbor for the frond borer beetles (either tunneling or oviposition sites) via exploiting the repellent potentiality of garlic extract. Although insect repellency of certain natural compounds had been practically addressed, the scientifically approved trials were few (Sritabutra et al. 2011). According to the obtained data, garlic extract succeeded to diminish palm frond infestation through its capability to deter $P$. frontalis beetles (re-orienting the beetles away from the garlic contaminated fronds).

Expansion of environmental interventions at date palm groves of the Egyptian oases as safe alternatives than conventional ones will participate in the sustainable management of date palm pest complex.

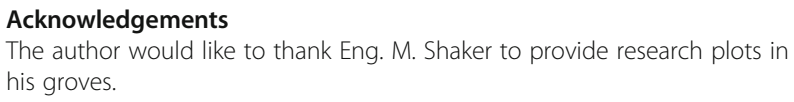

Funding

Desert Research Center is the funding body of the current research.

Availability of data and materials

Author confirms that all relevant data are included in the article and/or its supplementary information files.

Authors' contributions

I am the only author of this manuscript. So, I am responsible for all steps. The author read and approved the final manuscript.

\section{Ethics approval}

Not applicable.

Consent for publication

Not applicable.

Competing interests

The author declares that he has no competing interests.

\section{Publisher's Note}

Springer Nature remains neutral with regard to jurisdictional claims in published maps and institutional affiliations. 
Received: 6 November 2018 Accepted: 3 January 2019

Published online: 22 January 2019

\section{References}

Abass MH, Sabeh D, Esraa Al-Samir AH (2016) Morphological and biochemical impact of different decontamination agents on date palm (Phoenix dactylifera L.) procallus. Aust J Crop Sci. 10(7):1022-1029

Al-Deeb MA, Khalaf MZ (2015) Longhorn Stem Borer and Frond Borer of Date Palm. In: Wakil W, Faleiro JR, Miller TA (eds) Sustainable pest management in date palm: Current status and emerging challenges, sustainability in plant and crop protection. Springer Cham, Heidelberg New York Dordrecht London. https:/doi.org/10.1007/978-3-319-24397-9_1, Library of Congress Control Number: 2015958728

Al-Deeb MA, Mahmoud ST, Sharif EM (2012) Use of light traps and differing light color to investigate seasonal abundance of the date palm pest, Oryctes agamemnon arabicus (Coleoptera: Scarabaeidae). J Econ Entomol 105(6): 2062-2067

Al-Haideri HS, Al-Hafidh ENT (1986) Seasonal pests of palm and dates in the near east and North Africa. Regional project for Palm and Dates Research in the near east and North Africa (126 pp). Food and Agriculture Organization, Baghdad

Al-Ogale SM (2003) Biological study of the palm frond borer Phonapate frontalis (Fahraeus), Coleoptera: Bostrichidae. M.Sc., Fac. Sci., Tripoli Univ, at Al-Wahat, p 58

Ataia AM (2007) Phonapate frontalis F. (Coleoptera: Bostrichidae). M.Sc., Fac. Agri., Tripoli Univ, Al-Wahat, p 58

Bitaw AA, Ben-Saad AA (1990) Survey of date palm trees insect pests in Libya. Arab J Plant Prot 8(2):72-76

Broschat TK (2013) Palm morphology and anatomy. The environmental Horticulture Department, Florida Cooperative Extension Service, Institute of Food and Agricultural Sciences, University of Florida. ENH1212 available at: https://edis.ifas. ufl.edu/ep473. Accessed 24 Apr 2016

Erskine W, Moustafa AT, Osman AE, Lashine Z, Nejatian A, Badawi T, Ragy SM (2003) Date palm in the GCC countries of the Arabian Peninsula. Available on: http://agris.fao.org/agris-search/search.do?recordID=QV2005000026

FAOSTAT (2011) Crop production 2011, Statistics division, Food and Agriculture organization of United Nations

Hafiz ARS, Masood SB, Faqir MA, Farhan S, Rizwana B, Atif NA (2012) Aqueous garlic extract and its phytochemical profile; special reference to antioxidant status. Int J Food Sci Nutr 63(4):431-439

Henderson CF, Tilton EW (1955) Tests with acaricides against the brow wheat mite. J Econ Entomol 48:157-161

IBM SPSS Statistics for Windows (2013) Version 22.0. Armonk, New York

Imam Al (2012) Evaluation of some integrated managements to combat the greater date moth, Arenipses sabella Hmps. (Lepidoptera: Pyralidae), on date palm trees under Siwa Oasis conditions in Egypt. Egypt J Biol Pest Control 22(2):157-160

Karunamoorthi K, Hailu T (2014) Insect repellent plants traditional usage practices in the Ethiopian malaria epidemic-prone setting: an ethno botanical survey. J Ethnobiol Ethnomed 10: 22-32. https://doi.org/10.1186/1746-4269-10-2

Khalaf MZ, Alrubeai HF, Khudhaer MW, Abdulhusein AA (2017) Ecological sound control strategies for population suppression of date palm borers Oryctes spp. J Agric Sci Technol. A7:18-24. https://doi.org/10.17265/2161-6256/2017.01.003

Khalaf MZ, Alrubiae HF (2016) Impact of date palm borer species in Iraqi agroecosystems. Emir J Food Agr 28(1):52-57

Khalaf MZ, Al-Taweel AA (2014) Palm borers in Iraqi environment: Species, damages, methods of control. Republic of Iraq: Ministry of Science and Technology, Agricultural Research Directorate. (https:/www.researchgate.net/publication/ 329304996_Palm_Borers_in_Iraqi_Environment_Species-Damages-Methods_of_ Control_by)

Khattab AA, Helal H (1978) Population of Bostricopsis reichei Mars. and Phonapate frontalis F. caught by a light trap in Giza region as related to temperature and relative humidity. Agricultural research review 56:83-90

Liu LY, Schönitzer K, Yang JT (2008) A review of the literature on the life history of Bostrichidae (Coleoptera). Mitt Münch Ent Ges 98:91-97

Misak RF, Abdel Baki AA, El-Hakim MS (1997) On the causes and control of the water-logging phenomenon, Siwa Oasis, Northern Western Desert, Egypt. J Arid Environ 37:23-32

Nwachukwu ID, Asawalam EF (2014) Evaluation of freshly prepared juice from garlic (Allium sativum L.) as a biopesticide against the maize weevil, Sitophilus zeamais (Motsch.) (Coleoptera: Curculionidae). J Plant Prot Res 54(2):132-138
Riad M (1993) The date palm sector in Egypt, 45-53. In: Ferry M, Greiner D (eds) Le palmier dattier dans I' agriculture d' oasis des pays méditerranéens. CIHEAM Options Méditerranéennes: Série A. Séminaires Méditerranéens, Zaragoza n. 28

Robinson HS, Robinson PJM (1950) Some notes on the observed behavior of Lepidoptera in flight in the vicinity of light-sources together with a description of a light trap designed to take entomological samples. Entomol Gaz 1:3-20

Sritabutra D, Soonwera M, Waltanachanobon S, Poungjai S (2011) Evaluation of herbal essential oil as repellents against Aedes aegypti (L.) and Anopheles dirus Peyton \& Harrion. Asian Pac J Trop Biomed:S124-S128 https://doi.org/10. 1016/S2221-1691(11)60138-X

\section{Submit your manuscript to a SpringerOpen ${ }^{\circ}$ journal and benefit from:}

- Convenient online submission

- Rigorous peer review

- Open access: articles freely available online

High visibility within the field

- Retaining the copyright to your article

Submit your next manuscript at $\boldsymbol{\nabla}$ springeropen.com 